Vol 1. No. 3, Juli 2021 P-ISSN : 2774-8030, e-ISSN : 2774-8030

\title{
KONSTRUKSI PENDIDIKAN ISLAM DI ERA GLOBAL MENURUT AZYUMARDI AZRA
}

\author{
SITI NURUL WACHIDAH \\ Pengawas Madrasah Kemenag Kab. Magelang \\ e-mail: sitnoerwh.minkusecang@gmail.com
}

\begin{abstract}
ABSTRAK
Sistem pendidikan Islam di Indonesia belum menemukan bentuk yang ideal dalam menjawab tantangan perubahan di era global. Azyumardi Azra menawarkan ide-ide pembaharuan yang menarik untuk dikaji sebagai salah satu alternatif pemecahan problem pendidikan Islam. Problem akademik dalam penelitian ini; Pertama, bagaimana kritik Azyumardi terhadap pendidikan Islam dan bagaimana solusi yang ditawarkan. Kedua, bagaimana kekuatan dan kelemahan tawaran Azyumardi azra terhadap pendidikan Islam dalam Perspektif Filsafat Pendidikan Islam.Tujuan penelitian ini adalah untuk mengetahui kritik Azyumardi Azra terhadap pendidikan Islam dan solusi yang ditawarkannya, serta mengetahui kekuatan dan kelemahan tawaran Azyumardi Azra tentang konstruksi pendidikan Islam di era global dalam perspektif Filsafat Pendidikan Islam. Penelitian ini merupakan penelitian kepustakaan yang bersifat kualitatif. Pendekatan yang digunakan adalah pendekatan filsafat kritis dengan teori Filsafat Pendidikan Islam. Sumber data primer adalah karya-karya Azyumardi Azra yang terkait pembaharuan pendidikan Islam, sedangkan karya lain dijadikan sebagai data sekunder. Metode pengumpulan data adalah dokumentasi. Analisa data menggunakan content analysis. Temuan dalam penelitian adalah ide-ide pokok Azyumardi meliputi kritik epistimologi keilmuan Islam, paradigma pembelajaran, pengembangan Sumber Daya manusia. Kontribusi penelitian ini adalah tawaran Azyumardi Azra bagi konstruksi baru pendidikan Islam di era global meliputi pembelajaran emansipatoris, misi profetis sebagai dasar pengembangan SDM dan menawarkan model alternatif lembaga pendidikan Islam dengan Sekolah Elit Muslim dan madrasah unggul.
\end{abstract}

Kata Kunci : Azyumardi Azra, Pendidikan Islam, Filsafat Pendidikan Islam.

\section{PENDAHULUAN}

Kemajuan dunia pendidikan dapat dijadikan cermin kemajuan masyarakat serta memberikan kontribusi yang besar terhadap kemajuan suatu bangsa, sehingga pendidikan memperoleh perhatian yang besar dari setiap bangsa dan negara dalam mengatur kehidupan masyarakat.

Eksistensi penyelenggaraan pendidikan Islam di Indonesia masih berada dalam posisi yang problematik. Terlebih apabila dikaitkan dengan kerangka global atau yang disebut era informasi dan industrialisasi. Pendidikan Islam belum mampu memberikan tanggapan ketika dituntut perannya untuk mengatasi berbagai persoalan moral dan mentalitas bangsa, khususnya umat Islam di Indonesia (Azyumardi Azra, dalam Armai Arif, 2005).

Beberapa persoalan dalam pendidikan Islam di era global antara lain: Pertama, pendidikan Islam Krisis Konseptual. Kedua, Pendidikan Islam krisis Kelembagaan. Ketiga, adanya konflik antara tradisi pemikiran Islam dan pendidikan Islam modernitas. Keempat, pendidikan Islam krisis metodologi. Kelima, krisis orientasi. (Azyumardi Azra, dalam Syamsul Kurniawan,Erwin Mahrus, 2013). Berdasarkan persoalan di atas, maka pembaharuan pendidikan Islam sangat dibutuhkan, sebagai upaya mencari solusi terhadap permasalahan yang dihadapi di era global, dalam rangka mewujudkan tatanan pendidikan Islam yang berkualitas, berbasis modern dengan tidak meninggalkan konsep-konsep yang sudah mapan sebelumnya.

Menurut Azyumardi Azra (2002), bahwa perkembangan pendidikan Islam di Indonesia pada abad 21 bisa dikatakan berada di persimpangan jalan, maka lembaga pendidikan Islam dapat mengambil pilihan jalan tertentu, yang mengandung implikasi dan konsekuensi tertentu. 
Hali ini tidak hanya berkaitan dengan distingsi madrasah vis-a-vis dengan sekolah umum, tetapi juga dengan eksistensi madrasah itu sendiri di masa depan.

Berkaitan dengan pembaharuan pendidikan Islam, penting bagi umat Islam di Indonesia untuk tetap memperhatikan dan berpegang pada causa finalis pendidikan Islam, dalam rangka membina dan mendidik manusia menuju masa depan yang sukses. Menurut Suroyo (1991), langkah-langkah yang perlu dilakukan adalah: Pertama, pendidikan Islam harus menuju pada integrasi antara ilmu agama dan ilmu umum. Kedua, pendidikan Islam harus mencapai sikap dan perilaku toleran dan lapang dada, terutama dalam perbedaan penafsiran ajaran Islam, tanpa melepaskan pendapat dan prinsip yang diyakini. Ketiga, pendidikan harus mengintensifkan pemahaman bahasa Asing sebagai alat untuk menguasai dan mengembangkan ilmu pengetahuan. Keempat, pendidikan harus mampu menumbuhkan kemampuan berswadaya dan mandiri dalam kehidupan. Kelima, pendidikan harus menumbuhkan etos kerja, disiplin, jujur dan berorientasi pada nilai.

Tantangan di abad 21, menuntut respon yang tepat dari sistem pendidikan Islam secara keseluruhan, sehingga di persaingan global yang semakin tajam, kaum muslimin dapat survive dan tampil ke depan. Reorientasi pemikiran pendidikan Islam dan rekonstruksi sistem kelembagaan merupakan keniscayaan, dengan didukung ilmu pengetahuan dan teknologi.

Rumusan masalah dalam penelitian ini: Pertama, bagaimana kritik Azyumardi Azra terhadap pendidikan Islam dan solusi yang ditawarkan bagi konstruksi baru pendidikan Islam di era global. Kedua, bagaimana kekuatan dan kelemahan tawaran Azyumardi azrab tentang konstruksi baru pendidikan Islam di era global dalam perspektif Filsafat Pendidikan Islam.

Tujuan penelitian ini adalah untuk mendeskripsikan kritik Azyumardi Azra terhadap pendidikan Islam dan solusi yang ditawarkan bagi konstruksi baru pendidikan Islam di era global, serta untuk mengetahui kekuatan dan kelemahan tawaran azyumardi Azra tentang konstruksi baru pendidikan Islam di era global dalam perspektif Filsafat Pendidikan Islam.

Sedangkan manfaat penelitian adalah: Pertama, secara teoritis memberikan sumbangan pemikiran akademik bagi pengembangan pemikiran pendidikan Islam. Kedua, secara praktis memberikan masukan bagi pengelola lembaga pendidikan Islam dan instansi terkait dalam menetapkan kebijakan dan pengembangan pendidikan.

\section{METODE PENELITIAN}

Jenis penelitian ini adalah penelitian kepustakaan (Library Research), yang bersifat kualitatif. Pendekatan penelitian adalah filsafat kritis, untuk mengkaji secara kritis gagasan Azyumardi Azra tentang konstruksi pendidikan Islam di era global. Sumber data primer penelitian adalah data yang langsung berkaitan dengan tema pokok bahasan penelitian, yaitu dari karya Azyumardi Azra. Sedangkan data sekunder adalah data pendukung yang berkaitan dengan tema pokok bahasan penelitian, yaitu karya-karya yang relevan dengan pemikiran Azyumardi Azra tentang pembaharuan pendidikan Islam di Indonesia.

Metode pengumpulan data adalah dokumentasi, yaitu mencari data dari berbagai media dokumentasi, yang bersumber dari data primer dan sekunder. Kemudian dari beberapa referensi yang terkait dengan penelitian dilanjutkan dengan tahap penyeleksian terhadap data yang relevan. Selanjutnya dipisahkan dari karya-karya tertentu dari tokoh yang diteliti, terutama karya tentang pemikiran pembaharuan pendidikan Islam yang diambil dari sumber data primer dan sekunder.

Metode analisa data dalam penelitian ini adalah metode analisa isi (content analysisi), yaitu semua data yang berasal dari sumber penelitian dilakukan analisa, dan selanjutnya dicari makna yang terkandung terhadap pemikiran Azyumardi Azra dengan kaidah tertentu untuk mendapatkan kekuatan dan kelemahan dari pemikiran Azyumardi Azra, sehingga diperoleh pemikiran yang lebih komprehensif tentang pembaharuan pendidikan Islam. 


\section{HASIL DAN PEMBAHASAN}

\section{A. Hasil}

Terkait dengan pokok bahasan yang ada di tulisan ini, terdapat beberapa artikel jurnal yang telah dibuat oleh para penulis terdahulu. Salah satu tulisan tersebut ditulis oleh Wahyuddin Noor dengan judul "Azyumardi Azra: Pembaruan Pemikiran dan Kelembagaan Pendidikan Islam di Indonesia" (Noor, 2018). Berdasarkan artikel tersebut, Azra mengemukakan bahwa perubahan pemikiran dan kelembagaan merupakan prasyarat kebangkitan kaum muslimin di Indonesia. Pembaharuan pemikiran dapat dilakukan dengan adanya modernisasi dan demokratisasi pendidikan Islam. Artikel ini juga menegaskan bahwa Azyumardi Azra merupakan salah satu aktivis pembaharu kelembagaan pendidikan Islam. Hal tersebut dibuktikan selama beliau menjabat rektor di UIN Syarif Hidayatullah Jakarta, dan selama masa kepemimpinannya UIN Syarif Hidayatullah mengalami kemajuan yang belum pernah tercapai sebelumnya, yaitu perubahan status dari IAIN menjadi UIN.

Artikel kedua ditulis oleh Amiruddin dengan judul "Pemikiran Pendidikan Islam Menurut Prof. Dr. Azyumardi Azra, MA" (Amiruddin, 2016). Dalam artikel tersebut, Tujuan pendidikan secara esensial adalah terwujudnya peserta didik yang memahami ilmu-ilmu keislaman dan mengamalkannya dalam kehidupan sehari-hari. Dengan kata lain, terwujudnya insan kamil, yakni manusia yang kembali kepada fitrahnya dan kepada tujuan kehidupan nya sebagaimana ia berikrar sebagai manusia yang datang dari Allah dan kembali kepada Allah. Hal yang ditekankan dalam artikel ini adalah mengenai pemikiran Azyumardi Azra terhadap pendidikan Islam yakni perhatiannya terhadap demokratisasi dan modernisasi pendidikan Islam dengan tujuan agar mampu mengangkat martabat lembaga pendidikan islam yang menghasilkan kualitas tinggi. Dalam hal pembaruan, Azyumardi Azra menitikberatkan pada input dan output pendidikan Islam bagi masyarakat. Dengan memadukan nilai-nilai tradisional dan nilai-nilai yang berorientasi ke masa depan.

\section{Kritik Azumardi Azra terhadap Aspek Epistemologi dan Kelembagaan}

Masalah pokok yang masih menjadi polemik wacana pemikiran pendidikan Islam adalah hubungan antara Islam dan modernisme, modernisasi dan modernitas itu sendiri, walaupun secara doktrin hampir seluruh pemikir Islam modern sepakat tidak ada pertentangan antara Islam dan modernitas. Tapi jika Islam memang compatible dengan modernitas, sejauh mana modernitas dan modernisasi bisa ditoleransi? Hal tersebut memang menjadi persoalan yang hingga saat ini belum ada titik temu.

Azyumardi Azra (2008) mengemukakan bahwa modernitas dan modernisasi Barat dipandang gagal dalam memenuhi kesejahteraan lahir dan batin melalui kemajuan teknologi dan ilmu pengetahuan yang hal ini sebagian sudah terlanjur diadopsi kaum Muslim termasuk salah satunya dalam pendidikan. Kegagalan ini menurut kaum Muslim sering dikaitkan dengan epistemologi ilmu pengetahuan dan teknologi pasca Aufklarung dan revolusi industri di Eropa.

Terdapat juga perbedaan viewpoint terkait dengan epistemologi yaitu epistemologi yang bersifat antroposentris dan teosentris (Azyumardi Azra, 2008). Paradigma epistemologi antroposentris dapat dikatakan menggusur teosentris sepenuhnya di dunia barat, sedangkan terjadi tarik ulur antar paradigma tersebut di kalangan para pemikir Islam. Kelompok pemikir modernis, seperti Muhammad Abduh, terlibat dalam pengembangan paradigma yang bersifat antroposentris dan Sayyed Hussen Nasr, pemikir neo-tradisional, mengkritik keras paradigma tersebut dan memilih untuk menganjurkan paradigma teosentris. Pada puncaknya, muncullah gagasan untuk keluar dari epistemologis dengan adanya "Islamisasi Ilmu Pengetahuan" yang sampai sejauh ini belum terselesaikan.

Modernisasi sistem dan kelembagaan Islam yang dimulai sejak abad 20 sampai sekarang di Indonesia hampir sama sekali tidak menyentuh wacana epistemologis dan berjalan secara parsial dan sementara atau ad hoc (Azyumardi Azra, 2008). Hal tersebut meyebabkan kerumitan-kerumitan baru muncul dibanding memunculkan terobosan-terobosan baru yang dapat dipertanggungjawabkan. Modernisasi tersebut hanya bersifat involutif. 
Hal tersebut memunculkan permasalahan dalam tataran normatif pasca diberlakukannya Undang-Undang Sistem Pendidikan Nasional Nomor 20 Tahun 2003 terkait distingsi atau identitas Islam pada madrasah-madrasah. Hal pokok yang parut dipertanyakan adalah bagaimana identitas suatu madrasah apabila di dalam undang-undang tersebut madrasah dinyatakan sebagai "sekolah umum" yang berciri keagamaan. Dengan demikian, apakah ciri tersebut dapat diperoleh dengan adanya musholla atau dengan pembacaan basmalah sebelum kegiatan belajar mengajar menjadi kebiasaan rutin, atau terdapat standar lain. Hal tersebut menjadi sebuah ketidakjelasan bagi identitas madrasah. Distingsi tersebut harus dicarikan solusinya kemudian dirumuskan di tingkat epistemologis dan aksiologis ilmu-ilmu yang diajarkan, tetapi tentu hal tersebut tidak mudah.

Perkembangan modernisasi pendidikan Islam dimulai dengan adanya Pesantren Mamba'ul Ulum di Surakarta yang pada awalnya (1905) masih berciri tradisional, kemudian pada tahun 1915 melakukan uji coba memasukkan kurikulum pendidikan modern yang ditransformasikan ke dalam kurikulum pesantren. Perkembangan juga terjadi di Jawa dengan lahirnya Pesantren Modern Gontor yang mengambil sistem dan kelembagaan modern Belanda, serta memodernisasi sistem dan kelembagaan pendidikan Islam indigenous. Saat ini, semakin banyak pondok pesantren yang mulai memodernisasi sistem dan kelembagaan pendidikannya juga.

\section{Kritik Aspek Paradigma Pembelajaran}

Paradigma dapat diibaratkan sebagai suatu frame atau bingkai. Paradigma juga dapat berubah seiring berkembangnya waktu. Dalam hal pembelajaran, perubahan paradigma pembekajaran seyogyanya dilakukan dengan mengikuti permasalahan yang terus berubah dari waktu ke waktu di era global ini, sehingga peserta didik juga akan tanggap dan kompetitif dalam menghadapi era global (Azyumardi Azra, 2012). Menurut Azra, peralihan paradigma pendidikan yang berorientasi ke masa silam menuju orientasi ke masa depan dapat dilakukan dengan dua belas cara.

Cara-cara tersebut adalah pendidikan yang mengutamakan nilai kehidupan feodal aristokrasi menuju nilai kehidupan demokrasi, pendidikan yang membela kepentingan penguasa dan kekuasaan menuju kepentingan kerakyatan, pengelolaan pendidikan yang sentralistik menjadi pendidikan yang berbasis kekuatan masyarakat, peralihan pendidikan yang mengutamakan keseragaman menjadi menghargai keberagaman, manajemen yang memupuk ketergantungan menjadi manajemen yang mengutamakan kemandirian, pendidikan yang membuat masyarakat takluk kepada gaya pemerintahan melalui kebijaksanaan menjadi pendidikan yang menyadarkan masyarakat akan adanya kepastian hukum dan keteraturan, pendidikan yang mengutamakan konformisme nilai usang yang disakralkan menjadi pendidikan yang merintis pengembangan IPTEK, pandangan pendidikan yang lebih banyak bersifat pelaksanaan kewajiban menuju pandangan yang menyadarkan masyarakat mengenai HAM, orientasi pendidikan yang mengutamakan keseimbangan politik mmenjadi orientasi pendidikan yang mengutamakan perubahan dan kemajuan, sikap kependidikan yang memasung dan punitif menjadi motivatif, pendidikan yang tertutup dan terpola menjadi terbuka dan fleksibel, serta program kurikuler yang statis dan skolastik menjadi dinamis dan kontekstual.

Azra melontarkan kritik bahwa paradigma lama pembelajaran masih mendominasi. Hal tersebut membuat peserta didik menjadi terbelenggu dan kurang mendapat wadah untuk mengembangkan potensi yang dimilikinya. Pengembangan pendidikan selama ini terhambat oleh sistem yang sepotong-potong dan tidak menyeluruh. Tak mengherankan jika pendidikan Islam selalu kalah bersaing dalam banyak hal dengan sub-sistem pendidikan nasional. Kritik juga diarahkan terkait dengan teknologi pembelajaran, yaitu masih ada kecenderungan kuat bahwa teknologi pembelajaran terjebak dalam hal teknis terkait perumusan desain instruksional daripada yang bersifat substansial (Azyumardi Azra, 2012).

\section{Kritik Aspek Pengembangan Sumber Daya Manusia}


Pengembangan sumber daya manusia merupakan hal yang sangat penting untuk menghadapi tantangan-tantangan di era global seperti sekarang ini. Dalam era ini, kualitas dan pengembangan intelektual tidak dapat dipandang sebelah mata dan tuntutan untuk mengembangkan sumber daya manusia tak terelakkan karena dituntut adanya sumber daya manusia yang berkualitas, berintegritas dan unggul khususnya dibidang sains dan teknologi.

Azra menyampaikan kritik terkait dengan pengembangan sumber daya manusia yang unggul dibidang sains dan teknologi (Azyumardi Azra, 2012). Kritik-kritik tersebut yaitu lemahnya masyarakat ilmiah, kurang integralnya kebijaksanaan sains nasional, tidak memadainya anggaran penelitian ilmiah, kurangnya kesadaran di kalangan sektor ekonomi tentang pentingnya penelitian ilmiah, kurang mencukupinya fasilitas perpustakaan, dokumentasi, dan pusat informasi, terdapatnya isolasi ilmuwan, serta permasalahan birokrasi, restriksi dan insentif yang sangat kurang.

Era globalisasi juga memberikan dampak kepada masyarakat muslim indonesia pada umumnya serta pendidikan islam pada khususnya. Dampak dari adanya globalisasi dapat dirasakan baik dampak positif maupun negatif. Saat ini, memang harus diakui globalisasi lebih condong ke arah barat dengan hegemoni ekonomi dan sains teknologi. Hegemoni barat dibidang sains dan teknologi memberikan dampak berupa munculnya kemajuan di berbagai bidang, contohnya bidang informasi. Perkembangan tersebut tak terhindarkan dapat menyebabkan terkikisnya budaya luhur agama masyarakat. Oleh karena itu, diperlukan adanya perspektif etis dan panduan moral dalam penguasaan sains dan teknologi agar nilai-nilai yang tidak sesuai dapat disaring dan dihindari.

Keuntungan yang dimiliki Indonesia adalah masyarakatnya yang masih mempunyai pondasi nilai agama yang kuat. Dengan lebih diperkuatnya pengetahuan budaya dan agama, dampak negatif sains dan teknologi seharusnya dapat dihindari. Bahkan sains dan teknologi dapat memberikan dampak positif yang prospektif. Salah satu bukti tersebut adalah makin tumbuhnya antusiasme keberagamaan, atau lebih dikenal dengan kebangkitan agama (Azra, 2012). Hal tersebut tercermin dengan adanya pembangunan dan perkembangan pesantren. Dalam hal ini, pesantren sangat berpengaruh untuk membentuk karakter sumber daya manusia

Pengembangan SDM tidak dapat dipisahkan dari pengembangan intelektual. Intelektual berarti memiliki atau menunjukkan kekuatan penalaran yang baik (Homby, 1962). Intelektual yaitu orang yang mampu megembangkan pikiran, mencermati gejala-gejala sekitar yang terjadi dan hubungannya dengan gejala lain, kemudian dapat menyimpulkan dan dapat dikomunikasikan dengan bahasa yang jelas (Azra, 1998). Berhubungan dengan hal tersebut, terdapat juga cendekiawan, yaitu orang yang mempunyai kepedulian kemanusiaan dan problemnya, serta berupaya memberikan respon penyelesaiannya (Azra, 2000).

\section{Solusi Tawaran Azyumardi Azra bagi Konstruksi Pendidikan Islam a. Epistemologi Keilmuan Islam dan Transformasi Kelembagaan}

Azra menggunakan definisi epistemologis, yaitu ilmu yang membahas tentang keaslian, pengertian, metode dan validitas ilmu, untuk melihat epistemologi keilmuan Islam. Dalam hal ini, untuk keperluan praktis, menurut Azra, kitab kuning dipandang mempunyai sumber-sumber yang didasarkan pada Al Qur'an dan sunnah, serta akal juga memainkan peranan penting dalam konstruksi keilmuan kitab kuning (Azra, 2012). Tradisi kitab kuning sering menggunakan model ringkasan karya sebelumnya sehingga terdapat orisinalitas atau keaslian (syarah dan hasyiyah). Dengan demikian transmisi keilmuan model kitab kuning mempunyai peranan penting dalam penyebaran tradisi keilmuan Islam di Indonesia.

Dampak pengembangan epistemologis keilmuan Islam juga tampak dengan adanya islamisasi atau reislamisasi umat Islam di Indonesia. Istilah yang lebih populer dalam kecenderungan ini yaitu "santrinisasi". Proses santrinisasi tersebut mengalami akselerasi melalui lembaga pendidikan. Menurut Azra, perkembangan fenomena santrinisasi tampak dengan munculnya sekolah elit muslim yang menyatakan dirinya secara formal atau diakui oleh umat Islam sebagai sekolah Islam unggulan (Azra, 2012). Istilah elit dikarenakan sifatnya yang 
elit di bidang akademis serta seleksi yang ketat dan kompetitif baik untuk peserta didik maupun guru yang mengajar di sekolah tersebut.

Sekolah elit tersebut mempunyai pilar dalam pendidikan yaitu pendidilkan karakter dengan prinsip menjadikan Islam sebagai landasan filosofis, mengintegrasikan nilai Islam dalam kurikulum, mengedepankan uswah hasanah, menumbuhkan bid'ah sholihah, melibatkan orang tua untuk tercapainya tujuan pembelajaran, membudayakan nilai resik, rapi, ringkas, sehat dan asri, menjamin seluruh proses kegiatan sekolah untuk berorientasi pada mutu, dan menumbuhkan budaya profesionalsime (Azra, 2012). Sekolah elit tidak hanya terbatas pada sekolah Islam, tetapi juga muncul madrasah elit dalam perkembangannya. Salah satu madrasah elit yang terkenal adalah Madrasah Pembangunan Universitas Islam Negeri Syarif Hidayatullah Jakarta.

Menurut Azra, sekolah dan madrasah Islam elit menawarkan pendidikan yang berkualitas, dan memberikan kontribusi baik dalam perbaikan pendidikan Islam maupun dalam proses santrinisasi di Indonesia. Sekolah dan madrasah Islam elit pasti memberikan prospek yang lebih kepada peserta didik, serta memberikan pemahaman yang komprehensif tentang keilmuan Islam (Azra, 2012).

\section{b. Pembelajaran Emansipatoris}

Azra menawarkan sebuah paradigma pembelajaran dan pendidikan yang ideal di era global yaitu paradigma pembelajaran emansipatoris (Azra, 1996). Paradigma tersebut menekankan pembelajaran yang sejak dari pandangan dunia filosofis, sampai ke tingkat strategi, pendekatan dan proses serta teknologi menuju ke arah pembebasan peserta didik dalam segenap eksistensinya. Paradigma lama jelas berbeda dengan paradigma ini, karena justru menjadikan peserta didik terbelenggu dan tidak bebas mewujudkan keseluruhan potensi kependidikannya.

Pembelajaran dengan paradigma lama sudah banyak dikritik oleh beberapa tokoh dengan kritikan yang tajam ketika era globalisasi masih belum mencapai paradigma baru. Paulo Freire mengatakan bahwa sekolah telah gagal dalam pembelajaran peserta didik, karena sekolah terbelenggu dalam formalisme yang kaku. Sekolah bahkan membuat peserta didik terpasung dalam budaya bisu dan hilangnya kemampuan mengekspresikan diri. Peserta didik diasumsikan sebagai orang yang tidak tahu apa-apa sama sekali dan harus dijejali guru sesuai kemauannya sendiri (Azra, 2012).

Untuk menyikapi kecenderungan teknologi pembelajaran yang terjebak dalam hal teknis menyangkut perumusan desain instruksional daripada yang bersifat substansial, Azra menawarkan konstruksi pembelajaran kreatif dan inovatif, yaitu teknologi pembelajaran yang benar-benar fungsional haruslah beyond teknologi pembelajaran yang dapat disebut sudah konvensional, tidak hanya sekedar hal teknis dan terkait desain instruksional (Azra, 2012).

Pentingnya perubahan paradigma pembelajaran adalah untuk tujuan memberikan bekal bagi peserta didik dalam menghadapi perkembangan dunia di era global, sehingga dimiliki competitive advantage atau cutting edge di tengah persaingan yanng semakin ketat.

\section{c. Misi Profetis dan Pengembangan Sumber Daya Manusia}

Sub-bab ini sangat berhubungan dengan kemiskinan, karena pembahasan terkait pengembangan sumber daya manusia berkaitan erat dengan pengentasan kemiskinan. Upaya pengembangan sumber daya manusia dan pengentasan kemiskinan secara konseptual dan praktikal dilakukan dengan pendidikan Islam dan berhubungan dengan misi kenabian. Pemecahan dua persoalan tersebut sangat diperlukan untuk menuju kehidupan yang lebih adil, cerdas dan sejahtera.

Menurut Azra, pengentasan kemiskinan tidak dapat dilakukan dengan hanya menggunakan pendekatan materil saja, tetapi juga harus ada pendekatan non materiel, yaitu pengembangan sumber daya manusia (Azra, 2012). Pendidikan Islam adalah salah satu cara yang efektif untuk mengentaskan kemiskinan, tetapi waktu yang diperlukan mungkin sangat 
panjang. Terdapat banyak hal dalam ajaran Islam terkait dengan permasalahan pengentasan kemiskinan, contohnya anjuran kedermawanan. Anjuran tersebut berbentuk zakat, sedekah, infak, dan sebagainya. Tetapi, hambatan muncul karena pengelolaan yang dilakukan masih menggunakan metode tradisional dan menyebabkan tidak efektifnya hal tersebut secara fungsional. Pada tataran empiris, zakat, sedekah dan infak belum menumbuhkan mental produktif dan positif, tetapi malah konsumtif, karena pendekatan yang digunakan hanya sebatas pendekatan material dan belum menyentuk aspek non material.

Misi profetis Nabi Muhammad SAW adalah mendidik, menuntut, dan memimpin manusia untuk menuju ke jalan Allah SWT, serta mengajar mereka menjadi masyarakat yang adil, sejahtera secara material maupun spiritual serta sehat dan harmonis. Profetis berasal dari kata prophetic yang berarti kenabian atau berkenaan dengan nabi (Roqib, 2011). Profetis merujuk pada dua misi yaitu seorang yang menerima wahyu, diberi agama baru, dan diperintahkan mendakwahkan kepada umatnya (disebut rasul/messenger), sedangkan yang menerima wahyu dan tidak diperintahkan mendakwahkan kepada umatnya disebut nabi prophet (Eliade, 1987).

Oleh karena itu, misi sentral nabi yaitu peningkatan sumber daya manusia baik secara jasmaniyah maupun rokhaniyah, dan mengembangkan kualitas kehidupan manusia serta membekalinya dengan bekal yang diperlukan di dunia ataupun akhirat kelak (Azra, 2012).

Di era sekarang ini, perubahan kebutuhan manusia juga terjadi dengan cepat. Untuk mewujudkan fungsi idealnya dalam meningkatkan kualitas sumber daya manusia, sistem pendidikan Islam harus mengorientasikan diri untuk survive dan dapat menjawab tantangan yang ada dalam masyarakat. Kurikulum pendidikan Islam harus mengarah pada pembinaan dan pengembangan nilai agama dan harus memberikan penekanan khusus pada penguasaan sains dan teknologi. Dengan adanya hal-hal tersebut, pendidikan Islam dapat berfungsi untuk pembinaan sumber daya manusia dan pada gilirannya akan mempunyai implikasi terhadap pengentasan kemiskinan (Azra, 2012).

\section{B. Pembahasan Analisis Kekuatan dan Kelemahan Tawaran Azyumardi Azra 1. Analisis Epistemologi Keilmuan Islam dan Transformasi kelembagaan}

Berdasarkan pemaparan terdahulu, terdapat beberapa kritik Azyumardi Azra terhadap sistem pendidikan Islam tradisional. Azra, memang mengkritik sistem pendidilkan tradisional di tengah perubahan global tetapi hal tersebut bukan berarti sistem pendidikan Islam tradisional menjadi tidak relevan lagi. Seharusnya dua sistem tersebut dapat dijalankan secara beriringan karena menciptakan tradisi baru tidak harus berarti mencabut akar tradisi lama sehingga mata rantai keilmuan masih dapat terjaga dan tersambung.

Selanjutnya, pada prinsipnya Azra tidak menawarkan model epistemologi baru dalam mengkontruksi ilmu-ilmu keislaman. Azra hanyalah menganalisis kerumitan epistemologi keislaman untuk memasuki era global sehingga membutuhkan adanya modernisasi. Azra juga tidak menyatakan dengan tegas epistemologi apa yang dtawarkan dan diikuti. Menurut penulis, kemajuan-kemajuan modern dari barat masih dapat ditolerir asalkan tidak bertentangan dengan nilai universal dari Islam itu sendiri. Hal ini menunjukkan bahwa Azra telah kehilangan kritisnya terhadap dunia barat.

Dalam melihat modernisasi pendidikan di Indonesia, Azra juga terkesan masih melihatnya secara tidak utuh sehingga menimbulkan generalisasi dari persoalan dan memunculkan kesimpulan yang simplistik "modernisasi sistem pendidikan Islam tanpa basis epistemologi". Pergumulan epistemologi keilmuan Islam memang belum menemukan basis epistemologis yang pas, tetapi hal tersebut bukan menandakan bahwa tanpa epistemologi. Lebih tepatnya yaitu pengembangan pendidikan Islam di Indonesia masih berbasis epistemologi yang beragam.

Tidak dapat dipungkiri, memang kemajuan barat menjadi inspirasi bagi pengembangan pendidikan Islam, tetapi tidak sepenuhnya keilmuan barat bermanfaat bagi pengembangan keilmuan Islam. Harus terlebih dahulu dilakukan seleksi terhadap hal-hal yang bermanfaat saja. 
Khazanah klasik juga merupakan warisan keilmuan Islam yang sangat kaya sehingga tidak dapat diabaikan begitu saja. Masih banyak warisan keilmuan tersebut yang bermanfaat dengan adanya reinterpretasi baru sesuai dengan perkembangan pemikiran dan peradaban manusia.

Terkait dengan pembahasan sekolah atau madrasah elit, kesan yang dirasakan adalah sekolah atau madrasah tersebut hanya diperuntukkan untuk masyarakat dengan kemampuan ekonomi yang sanggup saja. Gagasan ini sebenarnya cukup bagus, tetapi masih terdapat kekurangan yaitu hanya kaum ekonomi kuatlah yang dapat menikmati dan mengaksesnya.

Gagasan-gagasan yang ditawarkan Azra memang sangat bagus, tetapi masih banyak terdapat hal yang tidak bisa diwujudkan. Pertimbangan harus melihat juga kondisi riil di tataran empiris agar pemahaman yang diberikan menjadi komprehensif. Semisal anggaran pemerintah di sektor pendidikan belum sepenuhnya memadai, serta insentif untuk para pengajar juga memprihatinkan. Rendahnya tingkat kesadaran masyarakat tentang pentingnya pendidikan juga harus diperhatikan.

\section{Analisis Paradigma Pembelajaran}

Paradigma sebagai frame dapat berubah dan berkembang sesuai dengan kebutuhan manusia. Paradigma haruslah bersifat dinamis, khususnya paradigma pendidikan di era globalisasi dan adanya modernisasi. Perkembangan paradigma pendidikan akan terus terjadi seiring dengan perkembangan berbagai aspek dalam kehidupan masyarakat.

Di era globalisasi, perubahan yang ditimbulkan sungguh luar biasa. Dunia pendidikan juga terkena imbas oleh adanya pergeseran dan perubahan ini. Globalisasi juga ditandai dengan adanya kemajuan di berbagai bidang, salah satunya adalah sains dan teknologi. Hubungannya dengan aspek pendidikan, guru bukan lagi dianggap sebagai satu-satunya sumber pengetahuan karena peserta didik dapat mengakses informasi tentang keilmuan yang disediakan oleh teknologi yang sudah jauh pesat berkembang di era sekarang. Oleh karena itu, guru harus bisa memposisikan diri agar dapat tetap berada di posisi sentralnya dalam poses pembelajaran.

Azra menawarkan konsep paradigma emansipatoris dalam hal ini. Sebenarnya paradigma yang di tawarkan oleh Azra tersebut sangat bagus. Paradigma pembelajaran yang sejak dari tingkat pandangan dunia filosofis sampai ke tingkat strategi, pendekatan, proses dan teknologi pembelajaran menuju ke arah pembebasan peserta didik dalam sepenuh eksistensinya. Paradigma tersebut jelas berbeda dengan paradigma lama yang cenderung membelenggu peserta didik dalam mengembangkan bakat dan potensi keilmuannya.

Secara filosofis memang paradigma tersebut merupakan tawaran brilian, tetapi penerapan dari paradigma tersebut tentu membutuhkan syarat dan pra syarat yang cukup dan memadai. Pra syarat dan syarat-syarat tersebut adalah profesionalitas guru, kecukupan dalam hal infrastruktur, adanya penguasaan sains dan teknologi, serta masih banyak syarat lain yang harus dipenuhi terlebih dahulu. Pemenuhan syarat-syarat tersebut tentu membutuhkan waktu yang relatif lama. Degan demikian, penerapan paradigma emansipatoris tidak dapat diterapkan dengan segera atau sesuai yang diidealkan dengan waktu cepat. Diperlukan strategi dan indikator serta tahapan-tahapan yang harus dipersiapkan terlebih dahulu dengan sungguhsungguh.

Di sisi lain, media informasi juga dapat memberikan dampak negatif. Peserta didik dapat saja malah terjebak pada informasi-informasi yang salah dan hal tersebut dapat merusak nilai moral dan agama pesera didik. Oleh karena itu, guru dan orang tua berkewajiban untuk tetap mendampingi peserta didik, sehingga peserta didik dapat terhindar dari bahaya dampak negatif media informasi tersebut. Memang diperlukan kerjasama untuk mewujudkan sistem pendidikan Islam yang ideal dan berkembang ke arah yang lebih baik. Kerjasama semua pihak sangat dibutuhkan dalam pengembangan ini.

\section{Analisis Misi profetis dan Pengembangan Sumber Daya manusia}

Dalam pembahasan sebelumnya, terlihat inspirasi Azra dalam hal pembangunan sumber daya manusia adalah Nabi Muhammad SAW. Hal tersebut sudah sangat tepat karena Nabi merupakan suri tauladan umat manusia di segala hal. Seorang muslim sejati adalah pengikut 
Nabi Muhammad SAWyang bertugas melanjutkan misi profetik dalam menciptakan masyarakat yang berakhlak dan maju.

Di sisi lain, Azra mengkonsepsikan manusia yang unggul dan berkualitas sebagai pribadi yang mirip dengan Nabi, misi profetik diidentikkan dengan tugas guru profesional yang tidak hanya menguasai ilmu pengetahuan sesuai dengan bidangnya tetapi juga menjadi panutan dan contoh bagi peserta didiknya. Pandangan Azra terkait sumber daya manusia yang unggul dan berkualitas memang masih bersifat sangat teoritis sehingga perlu langkah-langkah konkrit dalam mewujudkannya.

Konsep ini memang terkesan terlalu muluk-muluk atau terlalu tinggi apabila disandingkan dengan kenyataan atau realitas yang ada. Tidak mudah untuk menciptakan guru yang berkualitas. Sistem pendidikan yang dimiliki Indonesia, khususnya sistem pendidikan keguruan, juga masih butuh banyak pembenahan terlebih dahulu. Cita-cita yang diidealkan memang sangat bagus tetapi faktanya adalah sebaliknya. Ide yang ditawarkan Azra sangat bagus tetapi perlu untuk diperhatikan bahwa hal tersebut masih membutuhkan kerja keras untuk mewujudkannya.

Misi profetik dalam kenyataannya sangat berkaitan dengan pembangunan Indonesia menuju kehidupan yang adil, aman, serta sejahtera lahir dan batin. Penguasaan sains dan teknologi menjadi sebuah tuntutan di era global, namun tetap diperlukan panduan moral dan perspektif etis sehingga dampak negatif globalisasi dapat dihindari.

\section{KESIMPULAN}

Azyumadi Azra memberikan kritik dan solusi terhadap sistem pendidikan Islam di era global. Kritik-kritik tersebut adalah kritik terhadap aspek epistemologi dan kelembagaan, aspek paradigma pembelajaran, dan aspek pembangunan sumber daya manusia. Masalah pokok yang masih menjadi polemik wacana pemikiran pendidikan Islam adalah hubungan antara Islam dan modernisme, modernisasi dan modernitas itu sendiri, walaupun secara doktrin hampir seluruh pemikir Islam modern sepakat tidak ada pertentangan antara Islam dan modernitas.

Modernisasi sistem dan kelembagaan Islam yang dimulai sejak abad 20 sampai sekarang di Indonesia hampir sama sekali tidak menyentuh wacana epistemologis dan berjalan secara parsial dan sementara atau ad hoc. Hal tersebut meyebabkan kerumitan-kerumitan baru muncul dibanding memunculkan terobosan-terobosan baru yang dapat dipertanggungjawabkan. Modernisasi tersebut hanya bersifat involutif.

Dalam aspek paradigma pembelajaran, Azra melontarkan kritik bahwa paradigma lama pembelajaran masih mendominasi. Hal tersebut membuat peserta didik menjadi terbelenggu dan kurang mendapat wadah untuk mengembangkan potensi yang dimilikinya. Pengembangan pendidikan selama ini terhambat oleh sistem yang sepotong-potong dan tidak menyeluruh. Tak mengherankan jika pendidikan Islam selalu kalah bersaing dalam banyak hal dengan sub-sistem pendidikan nasional. Kritik juga diarahkan terkait dengan teknologi pembelajaran, yaitu masih ada kecenderungan kuat bahwa teknologi pembelajaran terjebak dalam hal teknis terkait perumusan desain instruksional daripada yang bersifat substansial.

Dalam aspek pembangunan sumber daya manusia, Azra menyampaikan kritik terkait dengan pengembangan sumber daya manusia yang unggul dibidang sains dan teknologi. Kritikkritik tersebut yaitu lemahnya masyarakat ilmiah, kurang integralnya kebijaksanaan sains nasional, tidak memadainya anggaran penelitian ilmiah, kurangnya kesadaran di kalangan sektor ekonomi tentang pentingnya penelitian ilmiah, kurang mencukupinya fasilitas perpustakaan, dokumentasi, dan pusat informasi, terdapatnya isolasi ilmuwan, serta permasalahan birokrasi, restriksi dan insentif yang sangat kurang.

Solusi yang ditawarkan Azra yaitu epistemologi keilmuan Islam dan transformasi kelembagaan, pembelajaran emansipatoris, serta misi profetis dan pengembangan sumber daya manusia. Dalam hal yang pertama, Azra menawarkan adanya pembelajaran kitab kuning dan juga adanya sekolah atau madrasah Islam elit. Kitab kuning dipandang mempunyai sumbersumber yang didasarkan pada Al Qur'an dan sunnah, serta akal juga memainkan peranan 
penting dalam konstruksi keilmuan kitab kuning. Sedangkan sekolah atau madrasah Islam elit dianggap berkualitas tinggi.

Pembelajaran emansipatoris adalah tawaran untuk solusi selanjutnya. Paradigma tersebut menekankan pembelajaran yang sejak dari pandangan dunia filosofis, sampai ke tingkat strategi, pendekatan dan proses serta teknologi menuju ke arah pembebasan peserta didik dalam segenap eksistensinya. Paradigma lama jelas berbeda dengan paradigma ini, karena justru menjadikan peserta didik terbelenggu dan tidak bebas mewujudkan keseluruhan potensi kependidikannya.

\section{DAFTAR PUSTAKA}

Undang-Undang Nomor 20 Tahun 2003 tentang Sistem Pendidikan Nasional.

Amiruddin. (2016). "Pemikiran Pendidikan Islam Menurut Prof. Dr. Azyumardi Azra, MA". Jurnal Kependidikan Islam, Vol. 6, No. 2,

Azra, A. (1998). Pembaharuan Pendidikan Islam. Jakarta: Amissco. . (1998). Esai-Esai Intelektual Muslim dan Pendidikan Islam. Jakarta: Logos. . (2000).Menuju Masyarakat Madani Gagasan, Fakta, dan Tantangan. Bandung: PT Remaja Rosdakarya. . (2008). Pendidikan Islam Tradisi dan Modernisasi Menuju Milenium Baru. Jakarta: Wacana Ilmu. . (2012). Pendidikan Islam: Tradisi dan Modernisasi di Tengah Tantangan Millenium III. Jakarta: Kencana Penada Media Group.

Eliade, M. (1987). The Ensiklopedia of Region. Vol 12. New York: MacMillan Publishing Company.

Homby, AS., EV. (1962). Gatenby, H. Wakefield. The Advanced Learner's Dictionary of Current English. Oxford: Second Edition.

Kurniawan, S, E, Mahrus. (2013). Jejak Pemikiran Tokoh Pendidikan Islam. Yogyakarta: ArRuzz Media.

Noor, W. (2018). Azyumardi Azra: Pembaruan Pemikiran dan Kelembagaan Pendidikan Islam di Indonesia. Jurnal Pendidikan Islam, Vol. 5, No. 1,

Roqib, M. (2011). Prophetic Education (Kontekstualisasi Filsafat dan Budaya Profetik dalam Pendidikan). Purwokerto: STAIN Press.

Soeroyo. (1991). Pendidikan Islam Antara Cita dan Fakta. Yogyakarta: Tiara Wacana. 